\title{
DIGITAL CONFIDENCE ENVIRONMENT IN PROCEDURE RELATIONSHIPS
}

Damir Kh. Valeev ${ }^{1}$

Anas G. Nuriev ${ }^{2}$

Abstract: The implementation of the legally proclaimed ideas and principles is ensured by the mechanism of intersectoral regulators which, being in constant relationship contribute to the solution of tasks set. But the mechanism established at the level of legal regulators cannot be isolated from the environment in which certain rules of conduct should be guided. This is due to the possible "artificiality" of the rules of behaviour, which can be expressed either in the fact that the rule exists, but there are no really existing social relations that can fall under the regulatory influence in this sector, or statutory regulators no longer meet the needs of social development due to their inability to regulate actually existing relations. All this determines the importance of studying the environment in which the system of statutory regulators will be created to achieve a specific goal and task. The strategy for the development of the information society in the Russian Federation for 2017 - 2030 defines the development of the information society as the goal and objective of the application of information and communication technologies. The construction of the information society, which will exist within the framework of the "electronic state", involves the "digitalization" of all sections of public relations, including such an important area as the administration of justice. Thus, the digital environment should also organically include procedural relationships that make it possible to exist.

Keywords: digital environment; ejustice; information society; procedural relations; right to judicial protection.

\section{Introduction}

Decree of the President of the Russian Federation dated 09.05.2017

\footnotetext{
${ }^{1}$ Kazan Federal University. e-mail: valeev55 @ gmail.com. Tel. 8432337213

${ }^{2}$ Kazan Federal University.e-mail: anasnuriev@ yandex.ru.Tel. 89872250255
} 
No. 203 has approved the information society development strategy in the Russian Federation for 2017 - 2030 [1]. It defines goals and objectives in the field of application of information and communication technologies aimed at the development of the information society. At the same time, an information society is referred by a strategy as a society in which information, the level of its application and accessibility fundamentally affect the economic and sociocultural living conditions of citizens.

Building an information society presupposes availability of a digital environment that provides equal opportunities for participants in the implementation of legal relations of their rights and obligations, taking into account the capabilities of modern information and communication technologies. These technologies create a stable connection between participants in legal relations and contribute to a more open and expeditious achievement of a certain result, mutually beneficial for participants in legal relations.

The digital environment as a comfortable environment in which data in digital form can be easily converted to all spheres of public relations has already gone beyond the definition given in GOST R 52292-2004 "National Standard of the Russian Federation. Information technology. Electronic exchange of information. Terms and definitions "[2]. In the standard, the digital environment is defined as the environment of logical objects used to describe (simulate) other environments (in particular, electronic and social) based on mathematical laws. This is already an environment that allows participants in relations to exercise their rights not only within the framework of substantive legal relations based on the equality of participants in relations, but also in procedural (subordinate) legal relations. They have a court as a mandatory subject on the basis of a system of normative regulators that take into account, on the one hand, technical regulations and standards, and on the other hand, the availability of technical capabilities to exercise rights in digital form $[3,4,5,6,7]$.

\section{Methods}

The methodological basis of the study was the general provisions of the procedural sciences: constitutional law, 
civil procedural law, administrative procedural law, criminal procedural law. In the study, the following methods of scientific knowledge were used: interdisciplinary, dialectical, sociological method.

\section{Results}

As a result of the study, tools were established that are aimed at building a digital environment of trust in procedural relations, taking into account the need to comply with legal guarantees for the implementation of the constitutional right to judicial protection. A system of legal prerequisites has also been established to ensure the viability of the digital environment in procedural relations.

\section{Discussion}

The strategy for the development of the information society in the Russian Federation for 2017 2030 establishes and states that information and communication technologies have become part of modern management systems in all sectors of the economy, in the fields of public administration, national defence, state security and law enforcement. The tasks include the application of new technologies in government bodies of the Russian Federation that ensure the use of e-government infrastructure for the provision of state-owned, as well as commercial and non-commercial services that are in demand by citizens.

Creating a digital environment that will contribute to the realization of rights, obligations and powers in digital form is impossible without human rights mechanisms to ensure its viability. An "informational" society functions in an environment where information becomes an important resource that can influence changes in living conditions. At the same time, the key issue is access to justice in the digital economy and the availability of trust in institutions in the digital environment.

The use of information and communication technologies has become a part of modern legal proceedings, and the task of a phased transition of state bodies to the use of the information infrastructure of the Russian Federation is being fixed at the regulatory level. A certain analysis of Russian justice should be carried out at the present stage of "creating an 
ecosystem of the digital economy of the

Russian Federation".

From the point of view of the development of a digital confidence environment in procedural relations, two elements are of paramount importance: 1) the existence of a system of statutory regulators and 2) the availability of infrastructure that ensures the functioning of the digital confidence environment.

As noted by a number of authors, the main goal of the area related to statutory regulation is the formation of a new regulatory environment. This environment should provide a favourable legal regime for the emergence and development of modern technologies, as well as for the implementation of economic activities related to their use in the digital economy. All this will require not only point changes in individual regulatory legal acts, but primarily systemic amendments to the basic industry laws [8]. The system of statutory regulators, laying the possibility of the existence of a digital confidence environment in procedural relations, can now be represented in the following form. Federal Law dated June 23, 2016 No.
220-FZ "On Amending Certain Legislative Acts of the Russian Federation Regarding the Use of Electronic Documents in the Activities of the Judiciary" [9] introduced a whole block of procedural rules aimed at "digitalizing" of procedural relations in four sources of law: Code of Civil Procedure of the Russian Federation [10], Code of Criminal Procedure of the Russian Federation [11], Arbitration Procedure Code of the Russian Federation [12], Administrative Procedure Code of the Russian Federation [13]. However, the introduction of these legislative norms removed only the key legal restrictions on the "digitalization" of the procedural branches of law aimed at realizing the constitutional right to judicial protection. At the same time, the definition of priority basic legal concepts and institutions necessary for the development of the digital economy in the procedural branches of law, for some reason, did not happen in the branch procedural sources, but only at the level of by-laws.

By order of the Judicial Department under the Supreme Court of the Russian Federation dated December 
27, 2016 No. 251 "On approval of the

Procedure for submitting documents to the federal courts of general jurisdiction in electronic form, including in the form of an electronic document" (hereinafter Order No. 251) [14] the terminological apparatus applicable in civil, criminal and administrative proceedings within the framework of electronic justice has been developed and disclosed. In particular, the following categories are indicated: electronic document; electronic image of the document; electronic signature; electronic signature key; USIA (Unified system of identification and authentication); appeal to court; person filing documents with the court (user); information system "State Automated System - Justice"; Personal Area. Of course, these terms are not new, but it is important that these terms are disclosed precisely from the point of view of their procedural understanding and content.

However, the regulation of entire procedural institutions at the level of by-laws raises questions, in particular, on the procedure for filing an appeal to the court in electronic form and the subsequent procedure for the adoption of these appeals by the court. This, in our opinion, does not comply with the provisions of Art. 1, the Code of Civil Procedure of the Russian Federation, according to which the procedure for civil proceedings in federal courts of general jurisdiction is determined by federal laws.

For the development of a digital confidence environment in procedural relations, it is important to regulate legal issues related to the use of robotics and artificial intelligence tools. The legal doctrine actively discusses the issues of robotization of legal processes [15]. The issues of legal significance of digital data obtained in legal proceedings, including with respect to documents on paper, are also of fundamental importance.

From the point of view of the infrastructure that ensures the functioning of the digital confidence environment, the operation of remote resources that affect the initiation of proceedings in a court is indicative. So, at present, documents in electronic form can be submitted through the user's personal account, through the Internet portal of the State Automated System "Justice" (www.sudrf.ru) in the information and telecommunication network "Internet". At the same time, 
access to a personal account is carried out through identification and authentication in one of two possible ways: using a verified USIA (Unified system of identification and authentication) individual account or using an enhanced qualified electronic signature that a user has. In addition, judicial authorities can create procedural documents in digital form. So, for example, according to Article 199, the Code of Civil Procedure of the Russian Federation, when fulfilling the operative part of the decision in the form of an electronic document, an additional copy of this resolutive part of the decision is made on paper, which is also attached to the case.

An important step in the infrastructural support of the digital confidence environment will be executing the functions of monitoring and managing the data storage and processing infrastructure by the situational centre organization, as well as organizing by it the interaction in the process of eliminating threats to its operability and security. The Judicial Department under the Supreme Court of the Russian Federation, which currently solves a number of issues related to the implementation of certain elements of ejustice at the level of its own orders, could be considered as such a situation centre.

\section{Conclusions}

It can be concluded that the digital confidence environment is now at the initial stage of its formation in all four forms of administration of justice. The digital confidence environment in procedural relations can be described as the relationship between the court and the participants in the trial. It manifests itself in the possibility of exercising the procedural rights and obligations of participants in legal relations in digital form so that these actions have legal consequences and, on the other hand, in the activities of the court as an authority, which, by virtue of the powers it has, can influence the development of procedural relations in digital form.

\section{Acknowledgments}

The work is performed according to the Russian Government Program of Competitive Growth of Kazan Federal University. 


\section{Sireinere}

Periódico do Núcleo de Estudos e Pesquisas sobre Gênero e Direito

Centro de Ciências Jurídicas - Universidade Federal da Paraíba

V. 8 - $\mathrm{N}^{\mathrm{o}} 06$ - Ano 2019 - Special Edition

ISSN | 2179-7137 | http://periodicos.ufpb.br/ojs2/index.php/ged/index
The reported study was funded by RFBR according to the research project No. 18-29-16147 mk.

\section{References}

Decree of the President of the Russian Federation dated 05.09.2017 No. 203 "On approval of the Strategy for the development of the information society in the Russian Federation for 2017 2030" // Collected Legislation of the Russian Federation. - 05/15/2017. No 20. Art. 2901.

Order by the Federal agency for technical regulation and metrology "Rostekhregulirovanie" dated December 29, 2004 No. 135-st "On approval of GOST R 52292-2004 "National standard of the Russian Federation. Information technology. Electronic exchange of information. Terms and definitions "// M. : IPK Publishing house of standards, 2005.

Damir Kh. Valeev, Anas G. Nuriev., Rafael V. Shakirjanov Implementación del derecho constitucional a la protección judicial en los idiomas estatales del sujeto de la Federación Rusa
// Revista Dilemas Contemporáneos: Educación, Política y Valores. - Año: VI. -Número: Edición Especial . - Artículo no.:24. - Período: Diciembre 2018.

Nuriev A.G., Khodzhiev A.R, Procedural guarantees of rights of citizens of the Russian federation in the foreign states//Research Journal of Applied Sciences. - 2015. - Vol.10, Is.12. - P.832-834.

Safin Z.F. Legal Issues Supporting Production and Distribution of Biotech Products / E. V. Luneva, Z. F. Safin // International journal of Advanced biotechnology and Research. - 2016. Vol. 7. - № 4. - P. 1260-1264.

Valeev D.K., Golubtzov V.G. Modernization of the Russian law: a review of the laws on enforcement proceedings // Life Science Journal. 2014. №11(8s). P. 234-238.

Anas G. Nuriev. Características de la Responsabilidad Civil del Notario // Revista Dilemas Contemporáneos: Educación, Política y Valores. - Año: VI. -Número: Edición Especial . - Artículo no.:31. - Período: Diciembre 2018. 
Vaipan V.A. Legal regulation of the digital economy // Entrepreneurial law. 2018. - No. 1. - Pp. 12-17.

Federal Law No. 220-FZ dated June 23, 2016 “On Amending Certain Legislative Acts of the Russian Federation with regard to the Use of Electronic Documents in the Activities of the Judiciary" // Collected Legislation of the Russian Federation dated June 27, 2016. - No. 26 (Part I). - Art.3889.

The Code of Civil Procedure of the Russian Federation dated November 14, 1992// Collected Legislation of the Russian Federation. - November 18, 2002. - No. 46.- Art.4532.

The Code of Criminal Procedure of the Russian Federation dated December 18, 2001// Collected Legislation of the Russian Federation. - dated December 24, 2001 - No. 52 (part 1). - Art. - 4921.

The Arbitration Procedure Code of the Russian Federation dated 07.24.2002 No. 95-FZ // Collected Legislation of the Russian Federation. - dated July 29, 2002. - No. 30. - Art.3012.
Code of Administrative Procedure of the Russian Federation dated March 08, 2015// Collection of Legislation of the Russian Federation. - dated March 09, 2015. - No. 10. - Art.1391.

Order of the Judicial Department at the Supreme Court of the Russian Federation dated December 27, 2016 No. 251 "On approval of the Procedure for submitting documents to the federal courts of general jurisdiction in electronic form, including in the form of an electronic document" // Bulletin of acts on the judicial system.2017. No. 2 (February).Zuev D.S., Marchenko A.A.,

Khasyanov A.F. The use of text mining tools in jurisprudence // In the collection: Analytics and data management in areas with heavy data usage Collection of scientific papers of the XIX International Conference DAMDID / RCDL'2017. Edited by L.A. Kalinichenko, J. Manolopoulos, N.A. Skvortsova, V.A. Sukhomlina. 2017. P. 277-281 